\title{
Co-pyrolysis of lignite and rapeseed cake: a comparative study on the thermal decomposition behavior and pyrolysis kinetics
}

\author{
Elif Yaman $^{1}$ (D) Aysu Ulusal ${ }^{2} \cdot$ Başak Burcu Uzun $^{2}$
}

Received: 22 September 2020 / Accepted: 21 December 2020 / Published online: 11 January 2021

(c) The Author(s) 2021 OPEN

\begin{abstract}
In this study, physicochemical properties, co-pyrolysis kinetics and characteristics of lignite and rapeseed cake is investigated. While lignite has high calorific value, rapeseed cake has high volatile matter content and low moisture content that is suitable for the pyrolysis reactions. According to the thermal behavior of lignite and rapeseed cake blends, the addition of rapeseed cake into lignite provides to shift to lower initial decomposition temperature of blends compared to lignite. While rapeseed cake has a significant role in determining activation energies at the lower conversion degrees, lignite plays a vital role in specifying the activation energies at the higher conversion degrees. The char yield considerably decreases under the higher rapeseed cake ratio, while both of the bio-oil and gas yields increase. As conclusion, blending of rapeseed cake with lignite provides a positive synergy with regard to volatile yields and follows through different types of chemicals that can be valorized in various applications such as bio-chemicals and bio-fuel.
\end{abstract}

Keywords Co-pyrolysis $\cdot$ Lignite $\cdot$ Rapeseed cake $\cdot$ Thermogravimetry $\cdot$ Reaction kinetics

\begin{tabular}{|c|c|c|c|}
\hline \multicolumn{2}{|c|}{ Abbreviations } & \multirow[t]{2}{*}{ NIST } & \multirow{2}{*}{$\begin{array}{l}\text { The National Institute of Standards and } \\
\text { Technology }\end{array}$} \\
\hline A & Pre-exponential factor $\left(\mathrm{min}^{-1}\right)$ & & \\
\hline ASTM & American Society for Testing and Materials & $\mathrm{O}$ & Oxygen \\
\hline ATR & Attenuated total reflection & OFW & Ozawa-Flynn-Wall \\
\hline a.u. & Arbitrary unit & $\mathrm{Q}_{\mathrm{GVC}}$ & Gross calorific value (kJ/kg) \\
\hline$\beta$ & Constant heating rate & $\mathrm{R}$ & Universal gas constant $(8.314 \mathrm{~J} / \mathrm{K} \mathrm{mol})$ \\
\hline C & Carbon & $S$ & Sulphur \\
\hline $\mathrm{CO}_{2}$ & Carbon dioxide & $T$ & Transmission \\
\hline$C R$ & Coats-Redfern & $\mathrm{T}$ & Temperature (K) \\
\hline CV & Calorific value (MJ/kg) & $T_{f}$ & Temperature after reaction completed \\
\hline DTG & Derivative thermogravimetry & $\mathrm{T}_{\mathrm{i}}$ & Initial weight loss temperature \\
\hline$(\mathrm{dW} / \mathrm{dt})_{\max }$ & Maximum weight loss rates & $\mathrm{T}_{\mathrm{p}}$ & Peak temperature \\
\hline$E_{a}$ & Activation energy $(\mathrm{kJ} / \mathrm{mol})$ & TGA & Thermogravimetric analysis \\
\hline FT-IR & Fourier Transform Infrared Spectrometer & $w_{i}$ & Initial weight of the sample \\
\hline GC-MS & Gas Chromatography-Mass Spectrometer & $w_{f}$ & The weight after reaction completed \\
\hline $\mathrm{H}$ & Hydrogen & $w_{t}$ & The weight at time $t$ \\
\hline KAS & Kissinger-Akahira-Sunose & $x$ & Conversion \\
\hline $\mathrm{n}$ & Reaction order & & \\
\hline $\mathrm{N}$ & Nitrogen & & \\
\hline
\end{tabular}

Elif Yaman, elif.yaman@bilecik.edu.tr| ${ }^{1}$ Central Research Laboratory, Bilecik Şeyh Edebali University, 11210 Bilecik, Turkey. ${ }^{2}$ Department of Chemical Engineering, Faculty of Engineering, Eskişehir Technical University, 26555 Eskişehir, Turkey. 


\section{Introduction}

Currently, coal is the most used energy source in power generation in the amount of $36 \%$ in the world [1]. Coal is a type of mineral which is heterogeneous by chemically and physically. It includes high amount of carbon and lower amount of nitrogen and sulphur. Calorific value and quality of the coal is depending on its organic matter content like various hydrocarbons. According to its calorific value coal can be classified as anthracite, semi-anthracite, semibituminous, bituminous, sub-bituminous, lignite and hard coal [2]. The reserve of lignite in Turkey is approximately 8 billion tones which are more than raw petroleum and natural gas. Therefore, lignite that is used in thermal power stations has vital role among the other fossil fuel types in Turkey's energy demand. On the other hand, combustion of coal is caused $43 \%$ of $\mathrm{CO}_{2}$ emissions in the world with $28 \%$ of the emission from thermal power stations [3]. For this reason, there must be a development about coal-valorization to enhance of energy conversion and decrease emitting of $\mathrm{CO}_{2}$ [4].

Co-pyrolysis method is an important technique among other eco-friendly thermochemical conversion technologies that is an efficient way to obtain higher value fuel from polyolefins and coal. This method is also provides recovering of chemicals and less use of fossil fuels $[5,6]$. Another most important advantage of this method is that it helps to reduce the amount of solid waste by evaluating the waste biomass as well as coal $[7,8]$. Adding biomass to coal provides lower moisture to raw material, makes easier to grinding and improves the thermal availability. $\mathrm{CO}_{2}$ emission is decreased by blending coal with biomass because carbon in biomass was originated from atmospheric $\mathrm{CO}_{2}$ via photosynthesis. Therefore, carbon in biomass is $\mathrm{CO}_{2}$ neutral $[1,9]$. Synergistic effect of biomass on coal during co-pyrolysis has been widely studied. According to previous studies, gas-coal or char-coal interactions may be contributed to synergistic effects. The mass loss of the biomass and coal due to devolatilization of the raw material occurs during pyrolysis [10]. During pyrolysis, the reactions of depolymerization, vaporization and cross-linking of the coal-biomass blend yield the gaseous product, tar and char. Reaction rates and temperatures can be considerably different for biomass and coal pyrolysis $[11,12]$. Also, there is still different opinion about thermal devolatilization of the blend exist as independently or not while blending of biomass with coal. In addition to this, volatile products from biomass in lower temperature whether influence or not the thermal degradation rate of coal cannot be conclusively concluded [13]. This information can be clarified by performing both the kinetic analysis and analyzing the pyrolysis products together.
Kinetic analysis of pyrolysis reactions can be evaluated by applying thermogravimetric analysis [14]. Thermogravimetric analysis is also gave the thermal degradation behavior of solid raw material such as coal, biomass and their blends [15]. Therefore, it also gives information about the synergy between coal and biomass during thermal decomposition [16]. Some researchers prove that remarkable variations in the calculated kinetic parameters have been determined obtained by the methods with single heating rate. In order to ensure accuracy and repeatability between calculated kinetic parameters, methods using different heating rates should be conducted. Different heating rates are using to calculate and supply confidential assumptions of kinetic parameters in iso-conversional methods. Because of the methods are propped up to isoconversional premise, the modal-free methods offer that the degree of conversion is constant and the reaction rate is depended on the reaction temperature [17]. Thermogravimetric analysis specifies the mass loss during thermal degradation reactions of pyrolysis but it could not designate the composition of pyrolysis products [18]. So, in order to determine the composition of pyrolysis products, analytical pyrolysis experiments should be carried out.

In the current study, rapeseed cake was selected as feedstock besides lignite (as an important local coal reserve in Turkey) in order to specify not only the thermal and kinetic behaviors, but also to investigate the composition of pyrolysis products in fixed-bed pyrolysis. In Turkey, approximately 110,000 tons of rapeseed is produced per year [19]. Rapeseed which is an important energy plant is one of the most cultivated oil-plant over the world [20]. Since rapeseed is used as an energy plant in the industrial scale, a large amount of rapeseed cake is also obtained as waste. After the characteristics and kinetics of the pyrolysis was specified, rapeseed cake, lignite and their blends were pyrolyzed to obtain liquid products which were characterized by GC-MS.

\section{Materials and method}

\subsection{Preparation and characterization of rapeseed cake and lignite}

The rapeseed cake sample used in this study originated from the North West region of Turkey. Lignite samples were obtained from Seyitömer, Turkey. Air-dried samples were grounded by Armfield FT-7A cutting mill and sieved. Samples were characterized with proximate and ultimate analysis according to ASTM standards (E 897-82, 1102-84) $[21,22]$ and elemental analyzer (LECO, CHNS/628). Calorific values of the samples were calculating using Du-Long's formula [23]. 
$Q_{G V C}=338,2 C+1442,8\left(H-\frac{O}{8}\right)+94,2 S \quad(\mathrm{~kJ} / \mathrm{kg})$

The possible chemical functional groups present in rapeseed cake and lignite were investigated with using Perkin Elmer Spectrum 100 FT-IR in wave number range of $4000-400 \mathrm{~cm}^{-1}$ with Attenuated Total Reflection (ATR) module.

\subsection{Thermogravimetric analysis of rapeseed cake and lignite}

Thermogravimetric analysis (TGA) experiments were carried out in a SETERAM LabsysEvo Thermogravimetric analyzer. TGA instrument was used to quantify and record the weight loss data vs. increasing temperature. Approximately $10 \mathrm{mg}$ of sample (rapeseed cake:lignite, 100:0, $75: 25,50: 50,25: 75,0: 100)$ were inserted into alumina crucible, directly. All experiments were carried out under inert nitrogen $\left(20 \mathrm{~mL} \mathrm{~min}^{-1}\right)$ atmosphere for a range of temperature $25-900{ }^{\circ} \mathrm{C}$ with the heating rates of 10,30 and $50{ }^{\circ} \mathrm{C} \mathrm{min}^{-1}$. The continuous flow of nitrogen ensures an inert atmosphere on the sample.

\subsection{Kinetic analysis}

The thermal decomposition of a raw material in a nonisothermal conditions can be described as [24]:

$\mathrm{aA}($ solid $) \rightarrow \mathrm{bB}$ (solid) $+\mathrm{cC}$ (gas)

There are several model-fitting and model-free methods in literature that operated to determine of kinetic parameters [25-28]. Some of model-fitting and model-free methods are given in Table 1. In model-fitting methods reaction model, $f(x)$, should be proposed. Because of the biomass and coal degradation have numerously different reaction, some researchers proposed that simplifications while applying the model may not describe the complex reactions. Therefore, model-free methods were proposed on the degree of the conversion assumed to be constant and the reaction rate only depends on the reaction temperature. Model-free methods do not require any previous knowledge of the reaction mechanism or reaction scheme [29]. In this study, three different iso-conversional

Table 1 Model-fitting and model-free methods

\begin{tabular}{ll}
\hline Model-fitting methods & Model-free methods \\
\hline Differential & Friedman \\
Freeman-Carroll & Kissinger \\
Coats-Redfern & Ozawa-Flynn-Wall \\
& Kissinger-Akahira-Sonuse \\
\hline
\end{tabular}

methods: Kissinger-Akahira-Sunose (KAS), Ozawa-FlynnWall (OFW) and Coats-Redfern (CR) were carried out on TGA data of rapeseed cake, lignite and their blends. KAS and OFW methods are model-free methods while CR is a model-fitting method. Iso-conversional methods provide to calculate kinetic parameters without reaction mechanism knowledge. In the iso-conversional methods: (1) Temperature affects the reaction rate for a constant conversion, $x,(2)$ the reaction kinetics does not dependent on the heating rate. In addition to this, pyrolysis reactions are assumed to be in one-step process $[17,30]$.

Conversion, $x$, can be specified as:

$x=\frac{w_{i}-w_{t}}{w_{i}-w_{f}}$

here $w_{i}$ is the initial weight of the sample, $w_{t}$ is the weight at time $t$, and $w_{f}$ is the weight after reaction completed.

The thermal degradation rate of a raw material is:

$\frac{d x}{d t}=k(T) f(x)$

here $f(x)$ represents reaction model and $k(T)$ is described as the reaction rate constant. Arrhenius equation gives the temperature dependence:

$k(T)=A e^{\frac{-E_{a}}{R T}}$

here $E_{a}$ is the activation energy $\left(\mathrm{KJ} \mathrm{mol}^{-1} 1\right), \mathrm{T}$ is the temperature $(\mathrm{K}), \mathrm{R}$ is the universal gas constant $\left(8.314 \mathrm{~J} \mathrm{~K}^{-1} \mathrm{~mol}^{-1}\right.$ ) and $A$ is the pre-exponential factor $\left(\mathrm{min}^{-1}\right)$ [31].

$\frac{d x}{d t}=A e^{\frac{-E_{a}}{R T}} f(x)$

In constant heating rate $(\beta)$ conditions, temperature is a function of time:

$\beta=\frac{d T}{d t}=\frac{d T}{d x} \frac{d x}{d t}$

Combining Eq. 6 and Eq. 7:

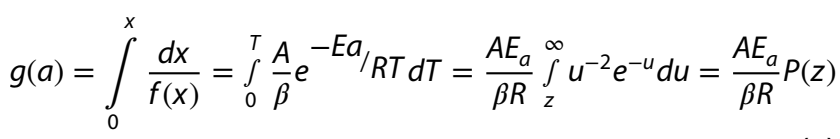

here $z=E_{a} / R T$. $P(z)$ has no exact solution. So, numerical methods or approximations have to be used to solve Eq. 7 . The iso-conversional methods names vary by the type of approximation method used [17].

\subsubsection{Kissenger-Akahira-Sunose (KAS) method}

$P(z)=z^{-2} e^{-z}$ approximation is used to solve Eq. 7 in KAS method. After rearrangement, the equation is: 
$\ln \left(\frac{\beta}{T^{2}}\right)=\ln \frac{A E_{a}}{R g(x)}-\frac{E_{a}}{R T}$

In the plot of $\ln \left(\beta / T^{2}\right)$ versus $1 / T$, slope gives $-E_{a} / R$. By calculation in a conversion range $0<x<1$, activation energy for the varying conversion values can be determined [32].

\subsubsection{The Ozawa-Flynn-Wall (OFW) method}

Doyle's approximation [31] is used in (OFW) method which can be attributed as; $\log (\mathrm{P}(\mathrm{z})) \sim-2.315+0.457 \mathrm{z}$

By using Doyle's approximation in Eq. 8:

$\log [\beta]=\log \left[\frac{A E_{a}}{R g(x)}\right]-2.315-0.457 \frac{E_{a}}{R T}$

In the plot of $\log \beta$ vs $1 / T$, slope gives $-E_{a} / R$. By calculation in a conversion range $0<x<1$, activation energy for the varying conversion values can be determined [33].

\subsubsection{Coats-Redfern (CR) method}

CR method is one of the model-fitting methods which is derived from Arrhenius equation. Pre-exponential factor, reaction order and activation energy can be determined by applying $C R$ method.

In Eq. 6, the function $f(x)$ is used to identify first order reaction in solid-state:

$f(x)=(1-x)^{n}$

An asymptotic approximation using for the resolution of Eq. (11) [34],

$\ln \left[\frac{1-(1-x)^{1-n}}{T^{2}(1-n)}\right]=\ln \left[\frac{A R}{\beta E_{a}}\right]-\frac{E_{a}}{R T} \quad(n \neq 1)$

$\ln \left[-\frac{\ln (1-x)}{T^{2}}\right]=\ln \left[\frac{A R}{\beta E_{a}}\right]-\frac{E_{a}}{R T} \quad(n=1)$

In the plot of $\ln \left[\frac{1-(1-x)^{1-n}}{T^{2}(1-n)}\right]$ versus $1 / \mathrm{T}$, slope gives slope $-\mathrm{E}_{\mathrm{a}} / \mathrm{R}$ and an intercept of $\ln \left[\mathrm{AR} / \beta \mathrm{E}_{\mathrm{a}}\right]$.

$\ln \left[\frac{1-(1-x)^{1-n}}{T^{2}(1-n)}\right] \quad$ versus $1 / T(n \neq 1)$

$\ln \left[-\frac{\ln (1-x)}{T^{2}}\right]$ versus $1 / T(n=1)$

\subsection{Pyrolysis experiments}

The pyrolysis of the feed stocks was carried out in a fixed-bed reactor in nitrogen atmosphere with the flow rate of $100 \mathrm{~cm}^{3} \mathrm{~min}^{-1}$. Lignite and rape seed cake samples were blended homogeneously with the mass ratio of 100:0, 75:25, 50:50, 25:50 and 0:100. Raw materials and blends were placed into the reactor. The 316 stainless steel, $70 \mathrm{~mm} \mathrm{ID,} 400 \mathrm{~cm}^{3}$ volume reactor was externally heated by an electric furnace in which the temperature is measured by a thermocouple inside the bed. Pyrolysis experiments were conducted with a heating rate of $10^{\circ} \mathrm{C}$ $\mathrm{min}^{-1}$ from $25^{\circ} \mathrm{C}$ to $500^{\circ} \mathrm{C}$ (Fig. 1) [35]. The gaseous product was measured using a soap film during the pyrolysis experiments. A glass liner in $0{ }^{\circ} \mathrm{C}$ trap was used to collect liquid products that recovered in dichloromethane for characterization. The liquid product which contains aqueous and oil phase were separated and weighed. Char yield was calculated by weighing overall losses of the reactor while gas yield was specified via overall material balance.

\subsection{Characterization of pyrolysis oil}

GC/MS analyses for liquid samples were conducted with a Gas Chromatography and Mass Selective detector (Shimadzu, QP 2010). A thin film (30 m ×0.25 mm ×0.25 $\mu \mathrm{m}$ film thickness), TRB-5MS (Teknokroma) capillary column was used as separation column. Helium of $1 \mathrm{~mL} \mathrm{~min}{ }^{-1}$ was flowed as carrier gas. The temperature program was $40{ }^{\circ} \mathrm{C}$ for $5 \mathrm{~min}$ followed by $4{ }^{\circ} \mathrm{C} \mathrm{min} \mathrm{me}^{-1}$ heating rate of $260^{\circ} \mathrm{C}$. NIST library was used to identification of peaks from pyrolysis products.

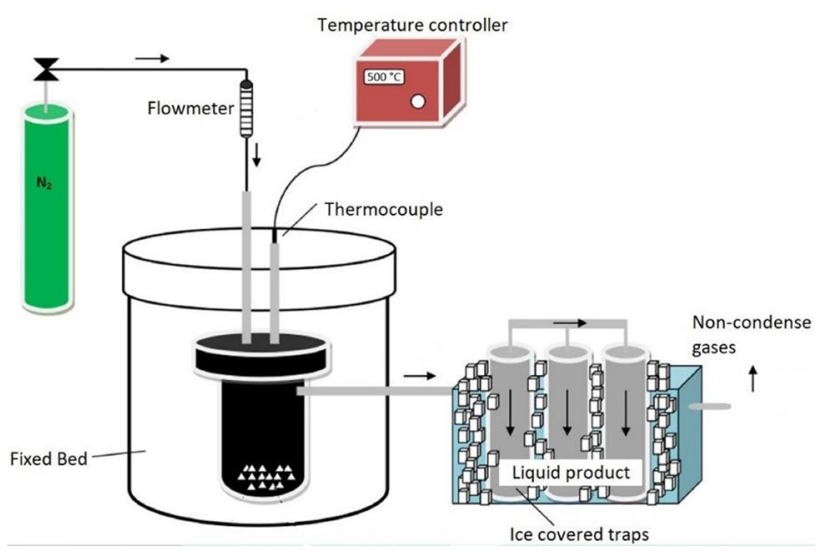

Fig. 1 Schematic diagram of the fixed-bed reactor (modified from [35]) 
Table 2 Ultimate analysis and calorific values of rapeseed cake and other energetic biomasses
Table 3 Proximate analysis of rapeseed cake and other energy biomasses

\begin{tabular}{lllllll}
\hline Biomass & $\mathrm{C}(\%)$ & $\mathrm{H}(\%)$ & $\mathrm{N}(\%)$ & $\mathrm{O}(\%)^{*}$ & $\mathrm{CV}(\mathrm{Mj} / \mathrm{kg})$ & References \\
\hline Rapeseed cake & 45.04 & 6.29 & 5.26 & 44.41 & 16.30 & Present study \\
Rapeseed cake & - & - & - & - & 23.40 & {$[20]$} \\
Rapeseed & 41.10 & 6.00 & 5.10 & 47.80 & 19.40 & {$[9]$} \\
Miscantus & 49.40 & 5.50 & 0.64 & 44.0 & - & {$[37]$} \\
Sweet sorghum & 45.71 & 5.80 & 0.33 & 48.16 & 18.57 & {$[38]$} \\
Switch grass & 44.90 & 5.98 & 1.58 & 47.50 & - & {$[39]$} \\
\hline
\end{tabular}

*Calculated by difference

\begin{tabular}{llllll}
\hline Biomass & $\begin{array}{l}\text { Volatile matter } \\
(\%)\end{array}$ & $\begin{array}{l}\text { Fixed carbon } \\
(\%)^{*}\end{array}$ & Ash (\%) & Moisture (\%) & References \\
\hline Rapeseed cake & 73.09 & 17.07 & 6.24 & 3.60 & Present study \\
Rapeseed cake & 79.44 & 8.34 & 4.56 & - & {$[20]$} \\
Rapeseed & 70.00 & 15.80 & 5.80 & 8.40 & {$[9]$} \\
Miscantus & 74.94 & 18.07 & 2.68 & 4.10 & {$[40]$} \\
Sweet sorghum & 76.33 & 15.98 & 3.53 & 4.17 & {$[38]$} \\
Switch grass & 84.20 & 11.90 & 3.90 & 8.40 & {$[41]$} \\
\hline
\end{tabular}

${ }^{*}$ Calculated by difference

\begin{tabular}{llllllll}
\hline Biomass & $\mathrm{C}(\%)$ & $\mathrm{H}(\%)$ & $\mathrm{N}(\%)$ & $\mathrm{S}(\%)$ & $\mathrm{O}(\%)^{*}$ & $\mathrm{CV}(\mathrm{Mj} / \mathrm{kg})$ & References \\
\hline Seyitömer Lignite & 67.20 & 4.62 & 1.19 & 0.90 & 26.09 & 24.88 & Present study \\
Huolinhe lignite & 57.92 & 4.78 & 0.83 & 0.43 & 36.04 & 21.67 & {$[42]$} \\
Lignite & 67.74 & 7.71 & 2.14 & 0.91 & 21.50 & - & {$[43]$} \\
Bituminous coal & 84.41 & 5.46 & 0.65 & 3.84 & 5.64 & - & {$[43]$} \\
\hline
\end{tabular}

${ }^{*}$ Calculated by difference

\begin{tabular}{llllll}
\hline Biomass & $\begin{array}{l}\text { Volatile mat- } \\
\text { ter }(\%)\end{array}$ & $\begin{array}{l}\text { Fixed carbon } \\
(\%)^{*}\end{array}$ & Ash (\%) & Moisture (\%) & References \\
\hline Seyitömer Lignite & 49.95 & 22.88 & 18.31 & 8.86 & Present study \\
Huolinhe lignite & 34.54 & 37.84 & 27.62 & - & {$[42]$} \\
Lignite & 37.99 & - & 16.67 & 17.92 & {$[43]$} \\
Bituminous coal & 32.20 & - & 13.01 & 0.69 & {$[43]$} \\
\hline
\end{tabular}

${ }^{*}$ Calculated by difference
Table 5 Proximate analysis of Seyitömer lignite and other coal samples biomass to be used as a renewable energy resource. Proximate analysis comparison of rapeseed cake with other energetic biomasses can be seen in Table 3. Rapeseed cake has a higher volatile matter content, $~ 73.09 \%$ which can be regarded suitable for pyrolysis, gasification or combustion processes. Ultimate and proximate analyses results of Seyitömer lignite and other coal samples are given in Tables 4 and 5. The characteristics of Seyitömer lignite were similar with other type of coals. According to the results, lignite is a carbon and oxygen rich coal containing $4.62 \%$ hydrogen, $1.19 \%$ nitrogen 
and $0.90 \%$ sulphur. The volatile matter content of Seyitömer lignite was higher than the other coal sample that is important to pyrolysis process. As expected, the rapeseed cake sample contains much higher proportions of volatiles than the lignite sample (Tables 3 and 5). The ash content was $18.31 \%$ for Seyitömer lignite and it between 13.01 and $27.62 \%$ for other coal samples. The low ash content is important to pyrolysis process because higher ash content may provoke aggregation and cause inefficient heat transfer rates [26].

FT-IR spectra results of rapeseed cake and lignite were given Fig. 2 and Table $6 . \mathrm{v}(\mathrm{O}-\mathrm{H})$ vibrations belonging to hydroxyl groups caused the band at $3400-3350 \mathrm{~cm}^{-1}$.
The band above $3500 \mathrm{~cm}^{-1}$ is ascribable to non-bonded $-\mathrm{OH}$ groups for phenols, alcohols and carboxylic acid. The band in the higher wavelength district $\left(3000-3500 \mathrm{~cm}^{-1}\right)$ is related to a large amount of -OH groups from carbohydrates and those of lignin and showed to the symmetric and asymmetric stretching vibrations correlated with $\mathrm{H}_{2} \mathrm{O}$ molecules $[44,45]$. The $\mathrm{O}-\mathrm{H}$ vibration band is seen in both rapeseed cake and lignite (Table 6). There is another intense band at around $1000 \mathrm{~cm}^{-1}$ attributable to C-O-R or C-O-H link in alcohols or esters. The band at $2925 \mathrm{~cm}^{-1}$ and $1400 \mathrm{~cm}^{-1}$ is ascribable to the stretching vibration of $\mathrm{C}-\mathrm{H}$ groups and bending vibrations of $-\mathrm{CH}_{2}$ and $-\mathrm{CH}_{3}$ groups in aliphatic chains, respectively. This aliphatic chain
Fig. 2 FT-IR spectrum of rapeseed cake and lignite

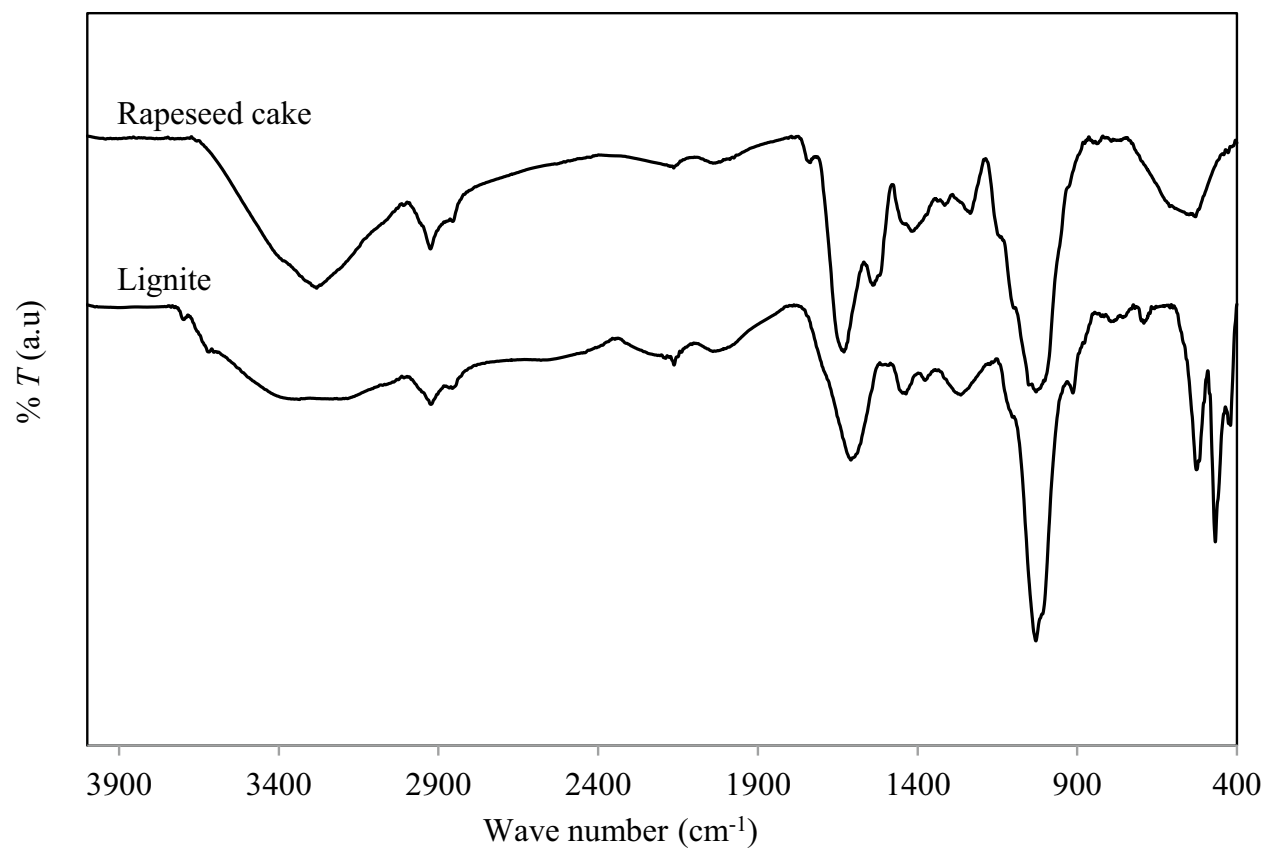

Table 6 Results of FT-IR spectra for rapeseed cake and lignite

\begin{tabular}{|c|c|c|c|}
\hline Band position $\left(\mathrm{cm}^{-1}\right)$ & Assignment & Rapeseed cake & Lignite \\
\hline $3600-3400$ & $\mathrm{u}(\mathrm{O}-\mathrm{H})$ & + & + \\
\hline $3040-3000$ & $\mathrm{u}(\mathrm{C}-\mathrm{H})$ aromatic ring & + & + \\
\hline 2980-2930 & $\mathrm{U}_{\mathrm{as}}(\mathrm{C}-\mathrm{H})$ & + & + \\
\hline $2870-2850$ & $\mathrm{u}_{\mathrm{s}}(\mathrm{C}-\mathrm{H})$ & + & + \\
\hline $1720-1770$ & $u(C=O)$ & + & - \\
\hline $1625-1590$ & $u(C=C)$ & - & + \\
\hline $1600,1580,1450$ & Aromatic ring & + & + \\
\hline 1460 & $\delta_{\text {as }}\left(\mathrm{CH}_{3}, \mathrm{CH}_{2}\right.$, scissor $)$ & + & - \\
\hline 1375 & $\delta_{s}(\mathrm{C}-\mathrm{H})$ & & + \\
\hline $1275-1200$ & $\mathrm{U}_{\mathrm{as}}(=\mathrm{C}-\mathrm{O}-\mathrm{C})$ & + & + \\
\hline $1150-1070$ & $\mathrm{v}_{\mathrm{as}}(\mathrm{C}-\mathrm{O}-\mathrm{C}) / \mathrm{OH}$ secondary, $\mathrm{OH}$ primary & + & + \\
\hline $900-700$ & Substituents of aromatic ring & + & + \\
\hline $740-720$ & $\gamma(\mathrm{C}-\mathrm{H})$ & - & + \\
\hline $730-675$ & $\gamma(\mathrm{C}=\mathrm{H})$ & - & + \\
\hline $720-725$ & Rocking band & - & + \\
\hline
\end{tabular}


is the basis structure of the common lignocellulosic biomass [46]. Carboxylic acid and carbonyl groups of esters in rapeseed cake are assignable with the peak around $1700 \mathrm{~cm}^{-1}$. The distinctive peak at around $1530 \mathrm{~cm}^{-1}$ is likely due to aromatic ring. Aliphatic and unsaturated aromatic compounds in the rapeseed cake structure can be indicated with the band at $1600 \mathrm{~cm}^{-1}$ [45]. The band about $1075 \mathrm{~cm}^{-1}$ is related to $\mathrm{U}(\mathrm{C}-\mathrm{O})$ vibration in the primary $\mathrm{C}-\mathrm{OH}$. Out of plane $-\mathrm{C}-\mathrm{H}$ bending vibrations were observed at nearly 733 and $697 \mathrm{~cm}^{-1}$ in lignite sample.

\subsection{Thermogravimetric analysis}

The thermogravimetric analysis curves of the individual materials (rapeseed cake and Seyitömer lignite) and their blends were shown in Fig. 3. It can be shown that the weight loss of the samples increased with raising temperature. The lower final weight loss of lignite compared to rapeseed cake was identified with the higher ash content and fixed carbon in lignite which was not degraded in this temperature. When the pyrolysis of lignite was finished, it yields a higher residue (66.63 wt \%), while rapeseed cake gave $36.54 \mathrm{wt} \%$ of residue under the same experimental conditions. While DTG curves of the samples were presented in Fig. 4, characteristic thermal degradation parameters were summarized in Table 7. The above parameters in the Table are initial weight loss temperature $\left(T_{i}\right)$, temperature after reaction completed $\left(T_{f}\right)$, the maximum weight loss rates $(\mathrm{dW} / \mathrm{dt})_{\max }$ and the peak temperatures $\left(\mathrm{T}_{\mathrm{p}}\right)$.

Addition of the rapeseed cake into lignite resulted in $T_{i}$ decreasing by $9-30{ }^{\circ} \mathrm{C}$ and $\mathrm{T}_{\mathrm{f}}$ reducing by about $9-29^{\circ} \mathrm{C}$. This indicated that the addition of rapeseed cake into lignite results in shifting to lower $T_{i}$ of the blends compared to that of lignite. From Fig. 4 and Table 3, a compare between the pyrolysis behavior of lignite and rapeseed cake can also be made. Rapeseed cake has a restricted degradation temperature gap than lignite. DTG curves emphasize the actual complexity in analyzing rapeseed cake-lignite blends; there was a single peak for devolatilization of lignite. Not surprisingly, DTG curve of rapeseed cake shows a completely wide peak with a shoulder; this thermal degradation profile mostly seen in biomass that is heterogeneous solid. Because, the component of biomass decomposed at different temperatures with different reaction rates. Like Idris et al. [30] and Yangali et al. [47], there was an increase in the peak height based on the mass loss rate as the weight percent of biomass raised for the first peak at lower temperature and a higher mass loss rate for the second peak as the coal fraction increases (Fig. 4).

\subsection{Kinetic analysis}

In current work, relation between activation energy and conversion was specified by applying KAS and OFW which are iso-conversional methods. The determined activation energies according to KAS and OFW methods are given at Table 8. The mean activation energies calculated from KAS method were 67.43, 98.71, 172.21, 206.73 and $96.22 \mathrm{~kJ} /$ mol for the blending ratio of 100:0, 75:25, 50:50, 25:75 and $0: 100$, respectively. In addition to this, the mean activation energies calculated from OFW method were 73.87, 103.47, $173.63,192.50$ and $102.44 \mathrm{~kJ} / \mathrm{mol}$ for the blending ratio of 100:0, 75:25, 50:50, 25:75 and 0:100, respectively. Due to the deviation of activation energies are varying between
Fig. 3 TG curves of of rapeseed cake:lignite blends

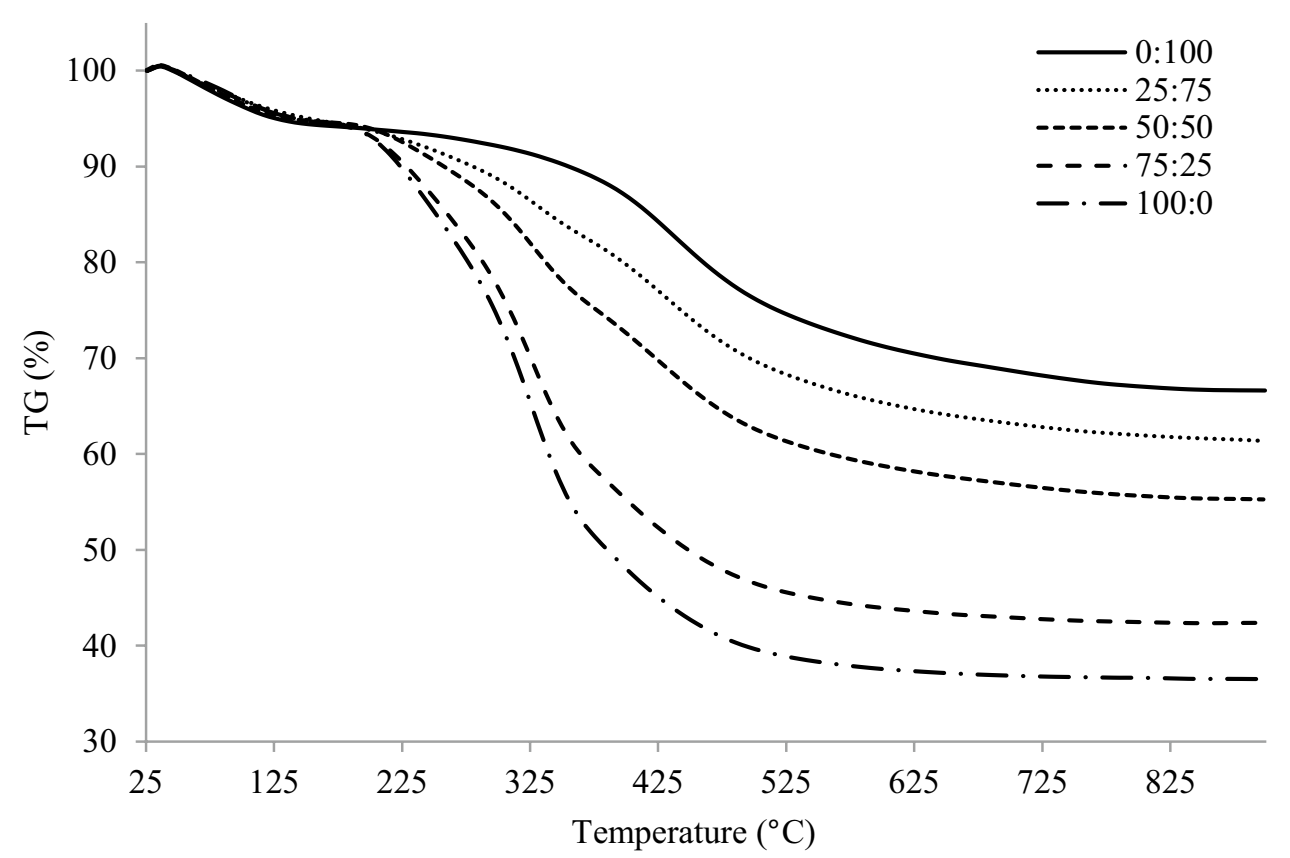

SN Applied Sciences 
Fig. 4 DTG curves of rapeseed cake:lignite blends

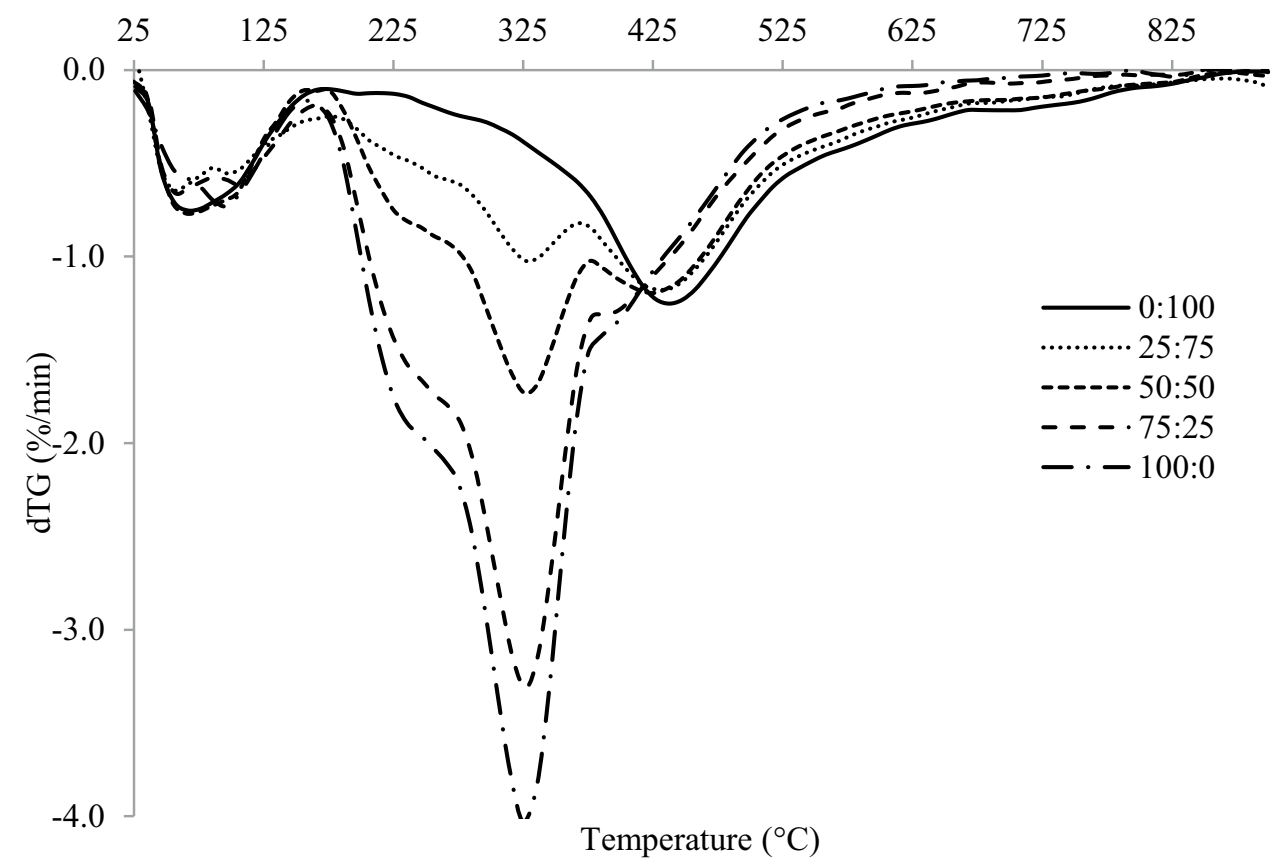

Table 7 Properties of active pyrolysis zone

\begin{tabular}{llllll}
\hline $\begin{array}{l}\text { Rapeseed } \\
\text { cake: lignite } \\
\text { ratio }\end{array}$ & $\begin{array}{l}\text { Pyrolysis } \\
\text { range } \\
\left({ }^{\circ} \mathrm{C}\right)\end{array}$ & $\begin{array}{l}\text { Peak tem- } \\
\text { perature } \\
\left({ }^{\circ} \mathrm{C}\right)\end{array}$ & $\begin{array}{l}\mathrm{dW} / \mathrm{dt}(\% \\
\left.\mathrm{min}^{-1}\right)\end{array}$ & Residue (wt\%) \\
\cline { 2 - 3 } & $\mathrm{T}_{\mathrm{i}}$ & $\mathrm{T}_{\mathrm{f}}$ & $\mathrm{T}_{\mathrm{p}}$ & & \\
\hline $100: 0$ & 146 & 605 & 315 & -3.76 & 36.54 \\
$75: 25$ & 156 & 748 & 317 & -3.31 & 42.37 \\
$50: 50$ & 175 & 757 & 315 & -1.63 & 55.29 \\
$25: 75$ & 177 & 768 & 427 & -1.15 & 61.37 \\
$0: 100$ & 186 & 777 & 437 & -1.23 & 66.63 \\
\hline
\end{tabular}

0.8 and $8.7 \%$, it can be said that the results obtained from KAS method in accordance with OFW method. This agreement confirms the confidingness of calculations and confirmed the predictive power of KAS and OFW methods
[17]. The activation energy of rapeseed cake at $x=0.2$ was higher being 58.09 and $63.47 \mathrm{~kJ} / \mathrm{mol}$, which was more than four times higher than lignite (11.30 and $14.77 \mathrm{~kJ} / \mathrm{mol})$. Increasing the blending ratio lead to an increase of activation energy in 75:25, 50:50 and 25:75 blending ratios. For example, when the blending ratio increased from 25:75 to 50:50, the activation energies of rapeseed cake-lignite blends increased from $33.03 \mathrm{~kJ} / \mathrm{mol}$ to $109.26 \mathrm{~kJ} / \mathrm{mol}$ (from KAS method). As shown in Table 3 and 5, the volatile matter content of rapeseed cake was $79.09 \%$, which was higher than the volatile matter content of lignite (49.95\%). The surface of the lignite may be covered with carbonaceous materials from the volatiles of rapeseed cake formed resulting in increased activation energies [1]. At the higher conversion degrees, lignite played a vital role in specifying the activation energies of blends. Generally, increased rapeseed cake ratio provides a decrease in activation
Table 8 Activation energies ( $\mathrm{JJ} / \mathrm{mol}$ ) for different conversion values using KAS and OFW models

\begin{tabular}{|c|c|c|c|c|c|c|c|c|c|c|}
\hline \multirow[t]{3}{*}{ Conversion } & \multicolumn{10}{|c|}{ Rapeseed cake: Lignite ratio } \\
\hline & \multicolumn{2}{|l|}{$100: 0$} & \multicolumn{2}{|l|}{$75: 25$} & \multicolumn{2}{|l|}{$50: 50$} & \multicolumn{2}{|l|}{$25: 75$} & \multicolumn{2}{|l|}{$0: 100$} \\
\hline & KAS & OFW & KAS & OFW & KAS & OFW & KAS & OFW & KAS & OFW \\
\hline 0.2 & 58.09 & 63.47 & 78.00 & 82.51 & 109.26 & 108.52 & 33.03 & 39.75 & 11.30 & 14.77 \\
\hline 0.3 & 66.98 & 72.40 & 114.71 & 117.95 & 219.38 & 217.76 & 70.88 & 89.74 & 54.37 & 61.53 \\
\hline 0.4 & 92.34 & 96.91 & 97.79 & 102.27 & 241.02 & 238.81 & 230.47 & 113.91 & 107.46 & 112.90 \\
\hline 0.5 & 135.57 & 138.39 & 98.49 & 103.25 & 274.65 & 271.25 & 135.98 & 140.00 & 157.28 & 160.81 \\
\hline 0.6 & 72.35 & 78.71 & 112.22 & 116.62 & 176.12 & 178.35 & 135.89 & 140.37 & 127.69 & 133.08 \\
\hline 0.7 & 36.73 & 45.58 & 88.92 & 94.85 & 121.51 & 127.21 & 203.25 & 204.94 & 112.31 & 119.02 \\
\hline 0.8 & 19.95 & 21.65 & 100.87 & 106.84 & 63.55 & 73.50 & 637.64 & 618.73 & 107.16 & 114.99 \\
\hline
\end{tabular}


energy of rapeseed cake:lignite blends. The decrease in activation energy with increasing rapeseed cake ratio can be explained by the fact that the components released by the volatilization of biomass facilitate the volatilization of coal, as explained in Sect. 3.3.1.

KAS and OFW methods are more confidential so, activation energies calculated from these models were used in Coats-Redfern equations for determination of pre-exponential factor. Determined pre-exponential factor values are given in Tables 9 and 10. The pre-exponential factor values calculated from these two methods are close to each other, confirming the reliability of the methods.
According to KAS and OFW models, activation energies versus $x$ values for different blending ratio were given in Fig. 5 . Figure 5 proved that $E_{a}$ is subjected to $x$ which means rapeseed cake and lignite co- and individual pyrolysis have complex reactions. For both values determined from KAS and OFW models $E_{a}$ increases while conversion increases from 0.2 to 0.5 . The variation in ea values due to the differences in reaction mechanism occurs with progressing conversion. Since Ea is minimum energy necessity to start a reaction Higher Ea values means slower reaction rates [28].
Table 9 Pre-exponential factors $\left(\mathrm{min}^{-1}\right)$ and $\mathrm{n}$ for different heating rates $\left({ }^{\circ} \mathrm{C} /\right.$ min) using $C R$ method with activation energies obtained from KAS model

\begin{tabular}{|c|c|c|c|c|c|c|}
\hline \multirow{3}{*}{$\begin{array}{l}\text { Rapeseed cake: } \\
\text { lignite ratio }\end{array}$} & \multicolumn{6}{|c|}{ Heating rate } \\
\hline & \multicolumn{2}{|l|}{10} & \multicolumn{2}{|l|}{30} & \multicolumn{2}{|l|}{50} \\
\hline & A & $\mathrm{n}$ & A & $\mathrm{n}$ & $A$ & $\mathrm{n}$ \\
\hline $100: 0$ & $1.3 \times 10^{3}$ & 0.01 & $3.7 \times 10^{7}$ & 2.3 & $5.7 \times 10^{9}$ & 5.3 \\
\hline $75: 25$ & $2.0 \times 10^{4}$ & 1.0 & $2.0 \times 10^{7}$ & 2.7 & $3.6 \times 10^{11}$ & 4.7 \\
\hline $50: 50$ & $7.8 \times 10^{3}$ & 1.0 & $9.5 \times 10^{7}$ & 4.7 & $1.7 \times 10^{8}$ & 4.8 \\
\hline $25: 75$ & $4.2 \times 10^{3}$ & 1.0 & $1.2 \times 10^{6}$ & 2.3 & $3.3 \times 10^{5}$ & 1.5 \\
\hline $0: 100$ & $2.7 \times 10^{2}$ & 0.9 & $1.5 \times 10^{3}$ & 1 & $2.2 \times 10^{5}$ & 2.3 \\
\hline
\end{tabular}

\begin{tabular}{|c|c|c|c|c|c|c|}
\hline \multirow{3}{*}{$\begin{array}{l}\text { Rapeseed cake: } \\
\text { lignite ratio }\end{array}$} & \multicolumn{6}{|c|}{ Heating rate } \\
\hline & \multicolumn{2}{|l|}{10} & \multicolumn{2}{|l|}{30} & \multicolumn{2}{|l|}{50} \\
\hline & A & $\mathrm{n}$ & A & $\mathrm{n}$ & $A$ & $\mathrm{n}$ \\
\hline $100: 0$ & $1.5 \times 10^{3}$ & 0.01 & $4.1 \times 10^{7}$ & 2.3 & $6.4 \times 10^{9}$ & 5.3 \\
\hline $75: 25$ & $2.1 \times 10^{4}$ & 1.0 & $2.1 \times 10^{7}$ & 2.7 & $3.8 \times 10^{11}$ & 4.7 \\
\hline $50: 50$ & $7.8 \times 10^{3}$ & 1.0 & $9.6 \times 10^{7}$ & 4.7 & $1.7 \times 10^{8}$ & 4.8 \\
\hline $25: 75$ & $3.9 \times 10^{3}$ & 1.0 & $1.1 \times 10^{6}$ & 2.3 & $3.0 \times 10^{5}$ & 1.5 \\
\hline $0: 100$ & $4.8 \times 10^{2}$ & 0.9 & $1.6 \times 10^{3}$ & 1 & $2.2 \times 10^{5}$ & 2.3 \\
\hline
\end{tabular}

Table 10 Pre-exponential factors $\left(\mathrm{min}^{-1}\right)$ and $\mathrm{n}$ for different heating rates $\left({ }^{\circ} \mathrm{C} /\right.$ min) using $C R$ method with activation energies obtained from OFW model
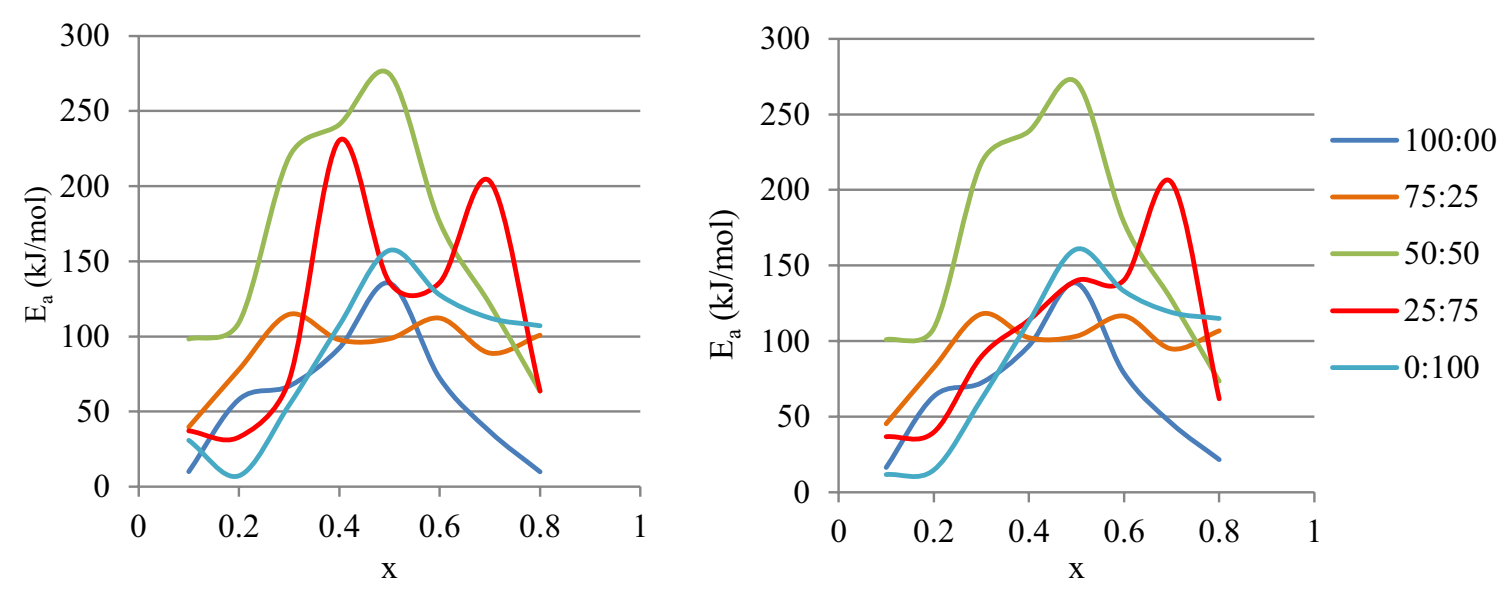

Fig. 5 Activation energies vs. $x$ values for different blending ratio a KAS model, b OFW model 
Pyrolysis reactions of coal are: (1) bond dissociation of aromatic rings such as naphthalene and phenanthrene (2) dissociation of free radicals (3) recombination of alpha radicals (4) hydrogen abstraction (5) addition of radicals to double bonds (6) addition of small radicals like $\mathrm{CH}_{3}$ and $\mathrm{C}_{2} \mathrm{H}_{5}$ to aromatic rings (7) reactions of carboxyl and phenolic hydroxyl groups [41]. Recombination of alpha radicals reactions are diffusion limited when they take place in the condensed coal phase. The carbonaceous materials occurring while rapeseed cake is volatiling may be covered to coal surface and it caused the reaction slow. Slower reactions means higher activation energies, so activation energy of coal pyrolysis was increased when $0.2<x<0.5$. Addition of small radicals to aromatic rings in coal reactions needs to an initiator which contains hydrogen. Jeong et al. [48] and Qiu et al. [49] has also reported that, the synergy of biomass and coal was higher between about 300-650 ${ }^{\circ} \mathrm{C}$ due to strong $\mathrm{H}_{2}$ promotion. Therefore, the release of hydrogen and hydroxyl radical from biomass can be attributed the catalyst for these reactions. Thus, with the beginning of hydrogen formation, the reaction rate increases and the activation energy decreases $(x>0.6)$. Possible co-pyrolysis reactions prediction for different conversion values were given in Table 11 [50].

\subsection{Pyrolysis experiments}

\subsubsection{Distribution of product yields}

Figure 6 showed the effects of blending ratios of rapeseed cake and lignite on the yield of products. According to Figure, when lignite and rapeseed cake were pyrolyzed alone at the temperature of $500{ }^{\circ} \mathrm{C}$, about $32 \mathrm{wt} \%$ of raw rapeseed cake is converted into bio-oil, however, only about $9 \mathrm{wt} \%$ of raw lignite is converted into bio-oil due to the fact that the rapeseed cake has greater pyrolysis reactivity. It is related that the $\mathrm{R}-\mathrm{O}-\mathrm{R}$ bonds of biomass are moderately weaker than $\mathrm{C}=\mathrm{C}$ bonds of coal [51]. In addition, the solid residue yield considerably decreased under the higher rapeseed cake ratio, but both of the bio-oil and gas yields increased. In the blends with high amount of biomass, the components obtained by the volatilization of

Table 11 Possible reaction prediction for different conversion values

\begin{tabular}{|c|c|c|}
\hline Conversion & $\mathrm{E}_{\mathrm{a}}(\mathrm{kJ} / \mathrm{mol})$ & Possible reactions \\
\hline $0.1-0.2$ & Low & Scission of weak bonds during volatilization of hemicellulose \\
\hline $0.2-0.3$ & High & $\begin{array}{l}\text { Beginning of straight chain scission in biomass, dissociation of free radicals and recombination of alpha radicals in } \\
\text { coal. }\end{array}$ \\
\hline $0.3-0.4$ & High & Decrease in polymerization degree of cellulose, shortening of chain length and convert to active cellulose. \\
\hline 0.5 & High & Beginning of active cellulose decomposition \\
\hline 0.6 & Low & Beginning of cellulose decomposition. Addition of small radicals to aromatic rings of coal. \\
\hline $0.7-0.8$ & Low & $\begin{array}{l}\text { Cross-linking of polymer chains and beginning of polycondensation reactions to form carbon-rich structures. } \\
\text { Reactions of carboxyl and phenolic hydroxyl groups in coal. }\end{array}$ \\
\hline
\end{tabular}

Fig. 6 Effect of blending ratios on pyrolysis products (Rapeseed cake:Lignite)

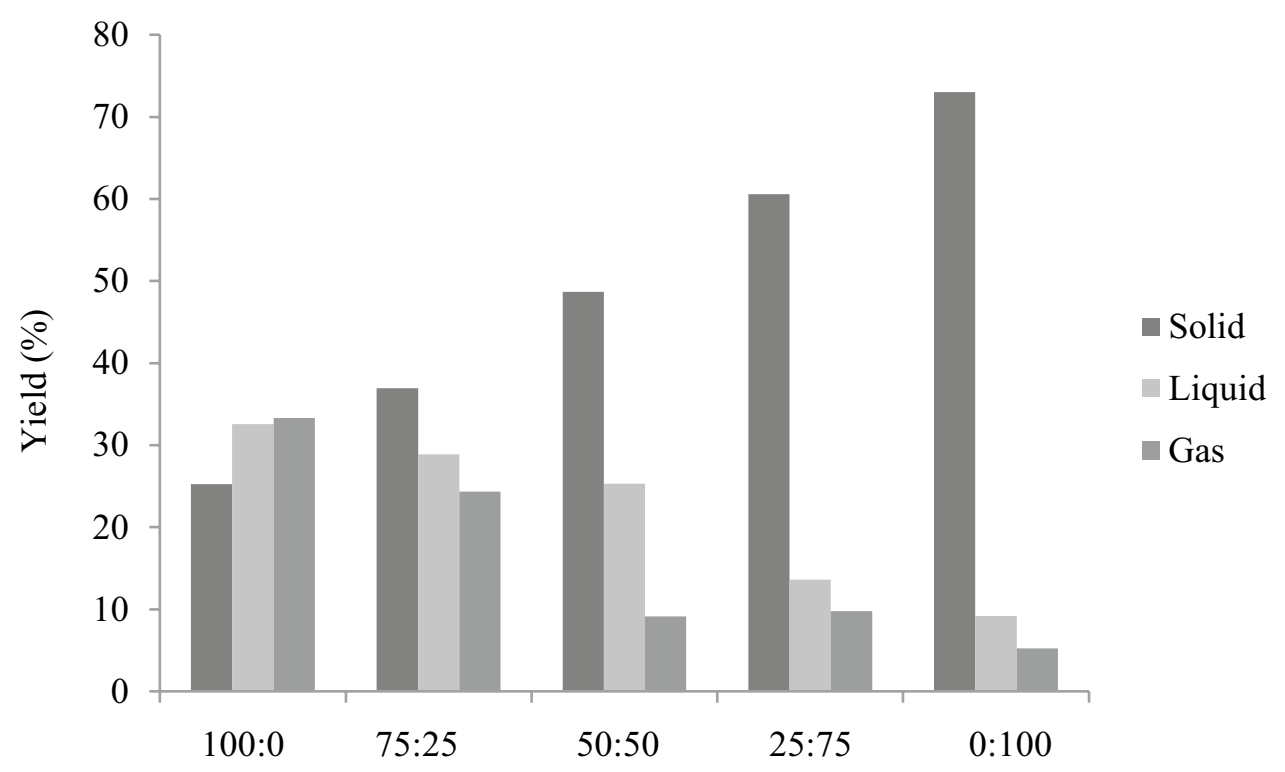

SN Applied Sciences 

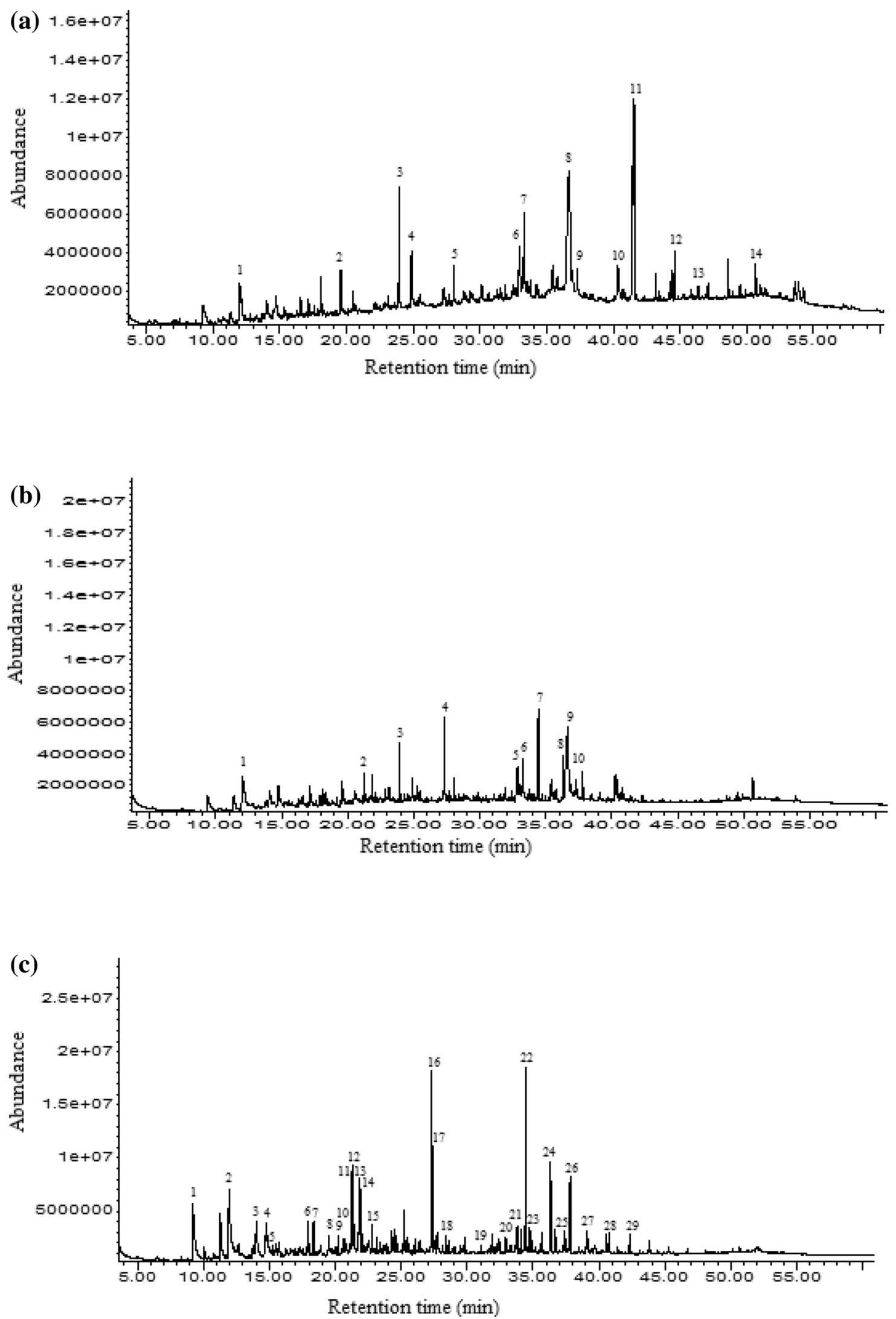

Fig. 7 GC/MS chromatogram of Rapeseed cake:Lignite blends a 100:0, b 50:50, c 0:100 
Table 12 GC/MS compounds of rapeseed cake:lignite blends (a) 100:0 (b) 50:50 (c) 0:100

\begin{tabular}{|c|c|c|c|c|}
\hline Retention time & Compound name & Molecular formula & Chemical group & Area \% \\
\hline \multicolumn{5}{|l|}{ (a) } \\
\hline 11.990 & P-Cresol & $\mathrm{C}_{7} \mathrm{H}_{8} \mathrm{O}$ & Phenolics & 3.19 \\
\hline 19.578 & Syringol & $\mathrm{C}_{8} \mathrm{H}_{10} \mathrm{O}_{3}$ & Phenolics & 4.29 \\
\hline 23.944 & 2,3,5-Trimethoxytoluene & $\mathrm{C}_{10} \mathrm{H}_{14} \mathrm{O}_{3}$ & Aromatics & 6.34 \\
\hline 24.876 & Isoeugenol & $\mathrm{C}_{10} \mathrm{H}_{12} \mathrm{O}_{2}$ & Phenolics & 4.43 \\
\hline 32.967 & $\begin{array}{l}\text { 5,10-Diethoxy-2,3,7,8-tetrahydro-1 } \mathrm{H}, 6 \mathrm{H} \text {-dipyrrolo } \\
\text { pyrazine }\end{array}$ & $\mathrm{C}_{14} \mathrm{H}_{22} \mathrm{~N}_{2} \mathrm{O}_{2}$ & Pyrazines & 6.68 \\
\hline 33.345 & Palmitic acid & $\mathrm{C}_{16} \mathrm{H}_{32} \mathrm{O}_{2}$ & Acids & 10.82 \\
\hline 36.635 & Oleic acid & $\mathrm{C}_{18} \mathrm{H}_{34} \mathrm{O}_{2}$ & Acids & 17.69 \\
\hline 36.721 & Oleic acid & $\mathrm{C}_{18} \mathrm{H}_{34} \mathrm{O}_{2}$ & Acids & 11.33 \\
\hline 40.430 & Phthalic acid & $\mathrm{C}_{8} \mathrm{H}_{6} \mathrm{O}_{4}$ & Acids & 11.10 \\
\hline 41.556 & 1,2-Propanediol, 3-benzyloxy-1,2-diacetyl & $\mathrm{C}_{14} \mathrm{H}_{18} \mathrm{O}_{5}$ & Aromatics & 13.87 \\
\hline 44.588 & Longicamphenylone & $\mathrm{C}_{15} \mathrm{H}_{24} \mathrm{O}$ & Ketones & 2.45 \\
\hline 46.605 & Triphenylbenzene & $\mathrm{C}_{24} \mathrm{H}_{18}$ & Phenolics & 1.91 \\
\hline 50.671 & Stigmastan-3,5-diene & $\mathrm{C}_{29} \mathrm{H}_{48}$ & $\mathrm{PAHs}$ & 2.37 \\
\hline \multicolumn{5}{|l|}{ (b) } \\
\hline 12.030 & Guaiacol & $\mathrm{C}_{7} \mathrm{H}_{8} \mathrm{O}_{2}$ & Phenolics & 15.46 \\
\hline 21.266 & Naphthalene, 2,6-dimethyl- & $\mathrm{C}_{12} \mathrm{H}_{12}$ & $\mathrm{PAHs}$ & 3.20 \\
\hline 23.932 & 3-Furoic acid, methyl ester & $\mathrm{C}_{6} \mathrm{H}_{6} \mathrm{O}_{3}$ & Aliphatics & 7.32 \\
\hline 27.308 & Methoxyeugenol & $\mathrm{C}_{11} \mathrm{H}_{14} \mathrm{O}_{3}$ & Phenolics & 11.24 \\
\hline 33.270 & Palmitic acid & $\mathrm{C}_{16} \mathrm{H}_{32} \mathrm{O}_{2}$ & Acids & 7.79 \\
\hline 34.426 & Palmitic acid & $\mathrm{C}_{16} \mathrm{H}_{32} \mathrm{O}_{2}$ & Acids & 10.54 \\
\hline 36.572 & Oleic acid & $\mathrm{C}_{18} \mathrm{H}_{34} \mathrm{O}_{2}$ & Acids & 15.42 \\
\hline 36.663 & Oleic acid & $\mathrm{C}_{18} \mathrm{H}_{34} \mathrm{O}_{2}$ & Acids & 17.10 \\
\hline \multicolumn{5}{|l|}{ (c) } \\
\hline 9.215 & Phenol & $\mathrm{C}_{6} \mathrm{H}_{6} \mathrm{O}$ & Phenolics & 3.48 \\
\hline 11.286 & Guaiacol & $\mathrm{C}_{7} \mathrm{H}_{8} \mathrm{O}_{2}$ & Phenolics & 14.18 \\
\hline 14.010 & M-Xylenol & $\mathrm{C}_{8} \mathrm{H}_{10} \mathrm{O}$ & Phenolics & 5.33 \\
\hline 14.697 & 3-ethylphenol & $\mathrm{C}_{8} \mathrm{H}_{10} \mathrm{O}$ & Phenolics & 2.07 \\
\hline 14.811 & P-Cresol & $\mathrm{C}_{7} \mathrm{H}_{8} \mathrm{O}$ & Phenolics & 4.60 \\
\hline 17.907 & a-Methylnaphthalene & $\mathrm{C}_{11} \mathrm{H}_{10}$ & $\mathrm{PAHs}$ & 0.68 \\
\hline 18.364 & p-Ethylguaiacol & $\mathrm{C}_{9} \mathrm{H}_{12} \mathrm{O}_{2}$ & Phenolics & 4.11 \\
\hline 19.503 & Lyratol & $\mathrm{C}_{10} \mathrm{H}_{16}$ & Aliphatics & 2.72 \\
\hline 20.230 & Cyclogeraniolane & $\mathrm{C}_{9} \mathrm{H}_{18}$ & Aromatics & 4.41 \\
\hline 21.191 & Naphthalene, 1,7-dimethyl- & $\mathrm{C}_{12} \mathrm{H}_{12}$ & $\mathrm{PAHs}$ & 1.17 \\
\hline 21.283 & Isoeugenol & $\mathrm{C}_{10} \mathrm{H}_{12} \mathrm{O}_{2}$ & Phenolics & 6.09 \\
\hline 21.700 & Naphthalene, 1,4-dimethyl- & $\mathrm{C}_{12} \mathrm{H}_{12}$ & $\mathrm{PAHs}$ & 1.17 \\
\hline 21.872 & Alpha-cedrane & $\mathrm{C}_{15} \mathrm{H}_{26}$ & $\mathrm{PAHs}$ & 5.14 \\
\hline 22.805 & 4,5-.Alpha,Alpha-Eudesmane & $\mathrm{C}_{15} \mathrm{H}_{28}$ & $\mathrm{PAHs}$ & 1.43 \\
\hline 27.337 & Phenol, 2,6-dimethoxy-4- (2-propenyl) & $\mathrm{C}_{11} \mathrm{H}_{14} \mathrm{O}_{3}$ & Phenolics & 9.97 \\
\hline 27.720 & n-Heptadecane & $\mathrm{C}_{17} \mathrm{H}_{36}$ & Aliphatics & 0.60 \\
\hline 28.384 & Cyclopropane, 1-methyl-2-pentyl & $\mathrm{C}_{9} \mathrm{H}_{18}$ & Aliphatics & 0.84 \\
\hline 31.868 & Nonadecane & $\mathrm{C}_{19} \mathrm{H}_{40}$ & Aliphatics & 0.76 \\
\hline 33.797 & Eicosane & $\mathrm{C}_{20} \mathrm{H}_{42}$ & Aliphatics & 2.09 \\
\hline 34.460 & Palmitic acid & $\mathrm{C}_{16} \mathrm{H}_{32} \mathrm{O}_{2}$ & Acids & 10.17 \\
\hline 35.651 & n-Heneicosane & $\mathrm{C}_{21} \mathrm{H}_{44}$ & Aliphatics & 0.83 \\
\hline 36.331 & $\begin{array}{l}\text { 5-acetyl-2-dihydro-6-methyl-2-oxo-4-phenyl- } \\
\text { 3-pyridinecarbonitrile }\end{array}$ & $\mathrm{C}_{9} \mathrm{H}_{8} \mathrm{~N}_{2} \mathrm{O}_{2}$ & Pyridines & 4.05 \\
\hline 37.419 & n-Docosane & $\mathrm{C}_{22} \mathrm{H}_{46}$ & Aliphatics & 0.84 \\
\hline 37.808 & Oleic acid & $\mathrm{C}_{18} \mathrm{H}_{34} \mathrm{O}_{2}$ & Acids & 5.23 \\
\hline
\end{tabular}


Table 12 (continued)

\begin{tabular}{|c|c|c|c|c|}
\hline Retention time & Compound name & Molecular formula & Chemical group & Area \% \\
\hline 39.118 & n-Tricosane & $\mathrm{C}_{23} \mathrm{H}_{48}$ & Aliphatics & 0.96 \\
\hline 40.749 & n-Tetracosane & $\mathrm{C}_{24} \mathrm{H}_{50}$ & Aliphatics & 0.81 \\
\hline 42.322 & Pentacosane & $\mathrm{C}_{25} \mathrm{H}_{52}$ & Aliphatics & 0.96 \\
\hline
\end{tabular}

the biomass are also higher. These components obtained by the volatilization of biomass also encourage the volatilization of coal. Thus, as the amount of biomass in the blend increases, the yield of bio-oil and gas increases while the yield of solid product yield decreases [30,47]. During the co-pyrolysis, occurring hydrogen from biomass is a vital factor which influence on the synergistic effect. In the meantime, inorganic contents of biomass act as a catalyst primary devolatilisation and secondary cracking reactions that is also decreased the activation energy and enhanced the liquid and gas product yields [1]. The solid product yield obtained from the pyrolysis reactor is different from the solid product amount at $500{ }^{\circ} \mathrm{C}$ in the thermograms obtained from the TGA experiments. The reason is the applied temperature programs are different. While the pyrolysis reactor was heated to $500^{\circ} \mathrm{C}$ and kept at this temperature in the pyrolysis experiments, the temperature was increased to $900{ }^{\circ} \mathrm{C}$ without waiting at $500{ }^{\circ} \mathrm{C}$ in the TGA experiments.

\subsubsection{GC/MS analysis of liquid product}

The chromatograms (Fig. 7a-c) showed significant release of liquid products which produced under different blending ratios. The relative concentrations of the identified chemicals were obtained by the relative percentage of peak area in Table 12. Accordingly, for all bio-oils the main components determined were aliphatic, acidic and phenolic compounds. It can be concluded that the compounds were detected in rapeseed cake-derived oil contained mainly acidic components, especially oleic acid, phthalic acid and palmitic acid. Furthermore, bio-oilderived rapeseed cake also consisted of phenolic compounds such as guaiacol and $p$-cresol which were typical derived products from the degradation of lignin polymers. Especially, bio-oil which derived from only lignite has more aliphatic compounds (17.75\%) in opposition to rapeseed cake. Acids can be classified as undesired product, because it leads to increase of the corrosivity of bio-oil. Phenolic and aliphatic compounds are desired products that can be used for the production of valuable chemicals such as fuels $[52,53]$. By conducted co-pyrolysis of lignite with rapeseeed cake, the yield of undesired product acids were decreased while the yield of desired product phenolic content was increased.

\section{Conclusion}

The present study involves both co-pyrolysis kinetics and characteristics of lignite and rapeseed cake. Characterization of physicochemical properties of a raw material is an important point to specify whether it is suitable for pyrolysis. According to the characterization results, lignite was a suitable raw material for pyrolysis due to its high carbon content and higher heating value. But for the enhancing the pyrolysis process, lignite has been blended with rapeseed cake which has high volatile matter content, low ash content, high carbon content and higher heating value. Thermogravimetric analysis summarized the coand individual pyrolysis behavior and kinetic parameters determination from this data proved that the activation energy is the function of conversion. Activation energy was also depended on biomass blending ratio. According to TG curves, rapeseed cake encouraged pyrolysis of the coal at lower temperatures. Rapeseed cake was acted as a hydrogen donor during the process and the higher rapeseed cake ratio provided less solid residue at the end of the pyrolysis reactions. By conducted co-pyrolysis of lignite with rapeseeed cake in a fixed bed reactor the yield of undesired product acids were decreased while the yield of desired product phenolic content was increased.

Acknowledgement The author would like to thank you the Central Research Laboratory, Bilecik Seyh Edebali University for TGA analyses and Department of Chemical Engineering, Eskisehir Technical University for pyrolysis experiments and GC/MS analyses.

Funding This research did not receive any specific grant from funding agencies in the public, commercial, or not-for-profit sectors.

\section{Compliance with ethical standards}

Conflict of interest The authors declare that they have no conflict of interest.

Open Access This article is licensed under a Creative Commons Attribution 4.0 International License, which permits use, sharing, adaptation, distribution and reproduction in any medium or format, as long as you give appropriate credit to the original author(s) and the source, provide a link to the Creative Commons licence, and indicate if changes were made. The images or other third party material in this article are included in the article's Creative Commons licence, unless indicated otherwise in a credit line to the material. If material is not included in the article's Creative Commons licence and your intended 
use is not permitted by statutory regulation or exceeds the permitted use, you will need to obtain permission directly from the copyright holder. To view a copy of this licence, visit http://creativecommons .org/licenses/by/4.0/.

\section{References}

1. Tian H, Jiao H, Cai J, Wang J, Yang Y, Bridgwater AV (2020) Copyrolysis of Miscanthus Sacchariflorus and coals: a systematic study on the synergies in thermal decomposition, kinetics and vapour phase products. Fuel 262:116603. https://doi. org/10.1016/j.fuel.2019.116603

2. Filho CDG, Milioli FE (2008) A thermogravimetric analysis of the combustion of a Brazilian mineral coal. Quim Nova 31(1):98-103. https://doi.org/10.1590/S0100-40422008000100021

3. Yılmaz AO (2008) Renewable energy and coal use in Turkey. Renew Energy 33:950-959. https://doi.org/10.1016/j.renen e.2007.04.022

4. Lin D, Liu L, Zhao YJ, Zhao Y, Qiu PH, Xie X, Sun SZ (2019) Physicochemical structure characteristics and intrinsic reactivity of demineralized coal char rapidly pyrolyzed at elevated pressure. J Energ Inst 93:1064-1073. https://doi.org/10.1016/j. joei.2019.10.001

5. Zhu J, Yang Y, Chen Y, Yang L, Wang Y, Zhu Y, Chen H (2018) Copyrolysis of textile dyeing sludge and four typical lignocellulosic biomasses: thermal conversion characteristics, synergetic effects and reaction kinetics. Int J Hydrog Energy 43(49):2213522147. https://doi.org/10.1016/j.ijhydene.2018.10.058

6. Fan H, Gu J, Hu S, Yuan H, Chen Y (2019) Co-pyrolysis and cogasification of biomass and polyethylene: thermal behaviors, volatile products and characteristics of their residues. J Energ Inst 92(6):1926-1935. https://doi.org/10.1016/j.joei.2018.11.002

7. Qi G, Wang Z, Zhang S, Dong Y, Guan J, Dong P (2020) Numerical simulation on biomass-pyrolysis and thermal cracking of condensable volatile component. Int. J. Hydrog. Energy 45:1228312297. https://doi.org/10.1016/j.ijhydene.2020.02.199

8. Wang Z, Liu G, Shen D, Wu C, Gu S (2020) Co-pyrolysis of lignin and polyethylene with the addition of transition metals-Part I: thermal behavior and kinetics analysis. J Energ Inst 93(1):281291. https://doi.org/10.1016/j.joei.2019.03.003

9. Haykiri-Acma H, Yaman S (2008) Thermal reactivity of rapeseed (Brassica napus L.) under different gas atmospheres. Bioresour Technol 99:237-242. https://doi.org/10.1016/j.biort ech.2007.01.001

10. Buessing L, Goldfarb JL (2012) Energy along Interstate I-95: pyrolysis kinetics of Floridian cabbage palm (Sabal palmetto). J Anal Appl Pyrolysis 96:78-85. https://doi.org/10.1016/j. jaap.2012.03.008

11. Vamvuka D, Kakaras E, Grammelis P (2003) Pyrolysis characteristics and kinetics of biomass residuals mixtures with lignite. Fuel 82:1949-1960. https://doi.org/10.1016/S0016-2361(03)00153-4

12. Vamvuka D, Pasadakis N, Kastanaki E (2003) Kinetic modeling of coal/agricultural by-product blends. Energ Fuel 17:549-558. https://doi.org/10.1021/ef020179u

13. Heikkinen JM, Hordijk JC, de Jong W, Splithoff H (2004) Thermogravimetry as a tool to classify waste components to be used for energy generation. J Anal Appl Pyrol 71:883-900. https://doi. org/10.1016/j.jaap.2003.12.001

14. Yu D, Hu S, Wang L, Chen Q, Dong N (2020) Comparative study on pyrolysis characteristics and kinetics of oleaginous yeast and algae. Int J Hydrog Energy 45:10979-10990. https://doi. org/10.1016/j.ijhydene.2020.02.052
15. Zhou W, Bai B, Chen G, Ma L, Jing D, Yan B (2018) Study on catalytic properties of potassium carbonate during the process of sawdust pyrolysis. Int J Hydrog Energy 43(30):13829-13841. https://doi.org/10.1016/j.ijhydene.2018.02.002

16. White JE, Catallo WJ, Legendre BL (2011) Biomass pyrolysis kinetics: a comparative critical review with relevant agricultural residue case studies. J Anal Appl Pyrolysis 91:1-33. https://doi. org/10.1016/j.jaap.2011.01.004

17. Ceylan S, Topçu Y (2014) Pyrolysis kinetics of hazelnut husk using thermogravimetric analysis. Bioresour Technol 156:182-188. https://doi.org/10.1016/j.biortech.2014.01.040

18. Ma Z, Xie J, Gao N, Quan C (2019) Pyrolysis behaviors of oilfield sludge based on Py-GC/MS and DAEM kinetics analysis. J Energ Inst 92(4):1053-1063. https://doi.org/10.1016/j.joei.2018.07.001

19. TurkStat (Turkish Statistical Institute) (2020). http://www.tuik. gov.tr/UstMenu.do?metod=temelist

20. Özçimen D, Karaosmanoğlu F (2004) Production and characterization of bio-oil and biochar from rapeseed cake. Renew Energ 29:779-787. https://doi.org/10.1016/j.renene.2003.09.006

21. ASTM Standart test method for volatile matter in analysis sample refuse derived fuel-3, In ASTM Annual Book of Ame. Soc. for Testing and Materials Standarts, Easton, M.D., USA, E-897-82, 1983

22. ASTM Standart test method for ash in wood, In ASTM Annual Book of Ame. Soc. for Testing and Materials Standarts, Easton, M.D., USA, D-1102-84, 1983

23. Uzun BB, Yaman E (2017) Pyrolysis kinetics of walnut shell and waste polyolefins using thermogravimetric analysis. J Energy Inst 90(6):825-837. https://doi.org/10.1016/j.joei.2016.09.001

24. Aboulkas A, El Harfi K, El Bouadili A, Ben Chana M, Mokhlisse A (2007) Pyrolysis kinetics of polypropylene. JTherm Anal and Calorim 89:203-209. https://doi.org/10.1007/s10973-007-7398-z

25. Uzun BB, Yaman E (2014) Thermogravimetric characteristics and kinetics of scrap tyre and Walnut shell co-pyrolysis. Waste Manag Res 32(10):961-970. https://doi.org/10.1177/07342 $42 \times 14539722$

26. Ceylan S, Topçu Y, Ceylan Z (2014) Thermal behaviour and kinetics of alga Polysiphonia elongata biomass during pyrolysis. Bioresour Technol 171:193-198. https://doi.org/10.1016/j.biort ech.2014.08.064

27. Mythili R, Venkatachalam P, Subramanian P, Uma D (2013) Characterization of bioresidues for biooil production through pyrolysis. Bioresour Technol 138:71-78. https://doi.org/10.1016/j.biort ech.2013.03.161

28. Gai C, Dong Y, Zhang T (2013) The kinetic analysis of the pyrolysis of agricultural residue under non-isothermal conditions. Bioresour Technol 127:298-305. https://doi.org/10.1016/j.biort ech.2012.09.089

29. Çepelioğullar Ö, Haykırı-Açma H, Yaman S (2016) Kinetic modelling of RDF pyrolysis: model-fitting and model-free approaches. J Waste Manag 48:275-284. https://doi.org/10.1016/j.wasma n.2015.11.027

30. Idris SS, Rahman NA, Ismail K (2012) Combustion characteristics of Malaysian oil palm biomass, sub-bituminous coal and their respective blends via thermogravimetric analysis (TGA). Bioresour Technol 123:581-591. https://doi.org/10.1016/j.biort ech.2012.07.065

31. Slopiecka K, Bartocci P, Fantozzi F (2011) Thermogravimetric analysis and kinetic study of poplar wood pyrolysis. Appl Energ 97:491-497. https://doi.org/10.1016/j.apenergy.2011.12.056

32. Fong MJB, Loy ACM, Chin BLF, Lam MK, Yusup S, Jawad ZA (2019) Catalytic pyrolysis of Chlorella vulgaris: kinetic and thermodynamic analysis. Bioresour Technol 289:121689. https://doi. org/10.1016/j.biortech.2019.121689 
33. Song Q, Zhao H, Jia J, Yang L, Lv W, Bao J, Xinqian S, Gu Q, Zhang $P(2020)$ Pyrolysis of municipal solid waste with iron-based additives: a study on the kinetic, product distribution and catalytic mechanisms. J Clean Prod. https://doi.org/10.1016/j.jclep ro.2020.120682

34. Doyle CD (1965) Series approximations to the equations of thermogravimetric data. Nature 207:290-291. https://doi. org/10.1038/207290a0

35. Ulusal A, Varol EA, Bruckman VJ, Uzun BB (2020) Opportunity for sustainable biomass valorization to produce biochar for improving soil characteristics. Biomass Convers Biorefin. https ://doi.org/10.1007/s13399-020-00923-7

36. Sait HH, Hussain A, Salema AA, Ani FN (2012) Pyrolysis and combustion kinetics of date palm biomass using thermogravimetric analysis. Biosour Tech 118:382-389. https://doi.org/10.1016/j. biortech.2012.04.081

37. Jong W, Pirone A, Wojtowicz MA (2003) Pyrolysis of Miscanthus Giganteus and wood pellets: tG-FTIR analysis and reaction kinetics. Fuel 82:1139-1147. https://doi.org/10.1016/S0016 $-2361(02) 00419-2$

38. Yin R, Liu R, Mei Y, Fei W, Sun X (2013) Characterization of biooil and bio-char obtained from sweet sorghum bagasse fast pyrolysis with fractional condensers. Fuel 112:96-104. https:// doi.org/10.1016/j.fuel.2013.04.090

39. Biney PO, Gyamerah M, Shen J, Menezes B (2015) Kinetics of the pyrolysis of arundo, sawdust, corn stover and switch grass biomass by thermogravimetric analysis using a multi-stage model. Bioresour Technol 179:113-122. https://doi.org/10.1016/j.biort ech.2014.10.155

40. Brosse N, Dufour A, Meng X (2012) Miscanthus: a fast- growing crop for biofuels and chemicals production. Biofuels Bioprod Bioref. https://doi.org/10.1002/bbb.1353

41. Imam T, Capareda S (2012) Characterization of bio-oil, syn-gas and bio-char from switchgrass pyrolysis at various temperatures. J Anal Appl Pyrolysis 93:170-177. https://doi.org/10.1016/j. jaap.2011.11.010

42. Mu L, Chen J, Yin H, Song X, Li A, Chi X (2015) Pyrolysis behaviors and kinetics of refining and chemicals wastewater, lignite and their blends through TGA. Bioresour Technol 180:22-31. https ://doi.org/10.1016/j.biortech.2014.12.090

43. Fei J, Zhang J, Wang F, Wang J (2012) Synergistic effects on copyrolysis of lignite and high-sulfur swelling coal. J Anal Appl Pyrolysis 95:61-67. https://doi.org/10.1016/j.jaap.2012.01.006
44. Özbay N, Uzun BB, Apaydın-Varol E, Pütün AE (2006) Comparative analysis of pyrolysis oils and its subfractions under different atmospheric conditions. Fuel Proces Techn 87:1013-1019. https ://doi.org/10.1016/j.fuproc.2006.07.009

45. Lopez-Velazquez MA, Santes V, Balmaseda J, Torres-Garcia E (2013) Pyrolysis of orange waste: a thermo-kinetic study. J of Anal and Appl Pyrolysis 99:170-177. https://doi.org/10.1016/j. jaap.2012.09.016

46. Mckendry P (2002) Energy production from biomass (part 1): overview of biomass. Bioresouce Tech 83:37-46. https://doi. org/10.1016/S0960-8524(01)00118-3

47. Yangali P, Celaya AM, Goldfarb JL (2014) Co-pyrolysis reaction rates and activation energies of West Virginia coal and cherry pit blends. J Anal Appl Pyrolysis 108:203-211. https://doi. org/10.1016/j.jaap.2014.04.015

48. Jeong HJ, Seo DS, Park SS, Hwang J (2015) A comprehensive study on co-pyrolysis of bituminous coal and pine sawdust using TG. J Thermal Anal Calorimetry 120:1867-1875. https:// doi.org/10.1007/s10973-015-4470-y

49. Qiu S, Zhang S, Zhou X, Zhang Q, Qiu G (2019) Thermal behavior and organic functional structure of poplar-fat coal blends during co-pyrolysis. J Renew Energ 136:308-316. https://doi. org/10.1016/j.renene.2019.01.015

50. Gavalas GR (1982) Coal pyrolysis, vol 4. Elsevier, Amsterdam

51. Guo M, Bi JC (2015) Characteristics and application of co-pyrolysis of coal/biomass blends with solid heat carrier. Fuel Proces Tech 138:743-749. https://doi.org/10.1016/j.fuproc.2015.07.018

52. Yaman E, Yargic AS, Ozbay N, Uzun BB, Kalogiannis KG, Stefanidis SD, Pachatouridou EP, Iliopoulou EF, Lappas AA (2018) Catalytic upgrading of pyrolysis vapours: effect of catalyst support and metal type on phenolic content of bio-oil. J of Clean Prod 185:52-61. https://doi.org/10.1016/j.jclepro.2018.03.033

53. Heracleous E, Lappas A, Serrano D (2017) Special thematic issue in Biomass Conversion and Biorefinery, Advances in catalytic biomass fast pyrolysis and bio-oil upgrading. Biomass Conv Bioref 7:275-276. https://doi.org/10.1007/s13399-017-0284-4

Publisher's Note Springer Nature remains neutral with regard to jurisdictional claims in published maps and institutional affiliations. 